\title{
MOLTMANN SPEAKING AT THE ECO- ENVIRONMENTALISTS CONFERENCE: ECOLOGY AND THEOLOGY IN DIALOGUE
}

\author{
Kelebogile Thomas Resane \\ Historical and Constructive Theology \\ University of the Free State
}

\section{Abstract}

This article explains Moltmann's doctrine of ecology as applied by ecotheologians to address the ecological crisis. Ecotheology is highlighted as a critical role-player in the harmonisation of theology and ecology. The role of ecotheology is defined within the ecological crisis in South Africa. The emergence of ecotheology assists scholars to balance and maintain a stable and theologically sensible mode of stewardship, taking a command from the perichoretical example for us to dwell together with God and creation as partners towards creation fulfilment. Moltmann's response to ecological abuse is to provide a Trinitarian theology of the environment that encompasses creation, redemption and anthropology. His theology of the environment attempts to widen its eschatological focus by stressing that humanity and the environment are being redeemed in the coming of God's Kingdom. Moltmann's trinitarian theology, especially from the perichoretical inter-relationship of the triune God, pneumatological application in creation, and humanity's pivotal position and role are all elaborated to support ecological understanding. Humanity as imago Dei are encouraged to move from the traditional view of dominating the earth towards that of becoming partners with God in the eschatological replenishment of the earth. Humans need to take a gigantic leap of acquiring knowledge of the trinitarian creation model suggested by Moltmann's ecological doctrine i.e. GodCreation-Humanity. Human beings must find out what their God-given meaning for the creation is, and when they have done so, their sense of responsibility will be ignited.

Keywords: Moltmann; Creation; Ecology; Ecotheology; Theology; Science; Humans; Nature

\section{Introduction}

The thesis statement of this article is that although Moltmann is vociferous in addressing current theological questions, he is less referenced, in the area of ecology. The aim is to bring to the surface his ecotheological convictions that are positioned in his trinitarian theology, in which God perichoretically dwells with nature. Invitation is extended to theology and ecology to engage in dialogue in order to see how these two sciences can work together toward good stewardship of the earth.

One theologian who has influenced my thinking regarding ecology and theology is a South African, Ernst Conradie of the University of the Western Cape. Apart from 
numerous journal papers on the subject, Conradie contributed entire books, such as Hope for the Church: Vistas on a New Century (2000/2005), An Ecological Christian Anthropology: At Home on Earth (2005), The Church and Climate Change (2008), Christianity and Earthkeeping: In Search of an Inspiring Vision (2011). His ecotheological epistemology is embodied in his work, The Earth in God's Economy: Creation, Salvation and Consummation in Ecological Perspective (2015), which is a narrative of the earth as part of God's economy, God's house-hold, which implies "fundamentally God's way of caring for us" (Conradie 2015:17). On the international front, famous ecotheologians include Pierre Teilhard de Chardin, Alfred North Whitehead, John B. Cobb, Niels Henrik Gregersen, and for this paper, a famous trinitarian theologian named Jürgen Moltmann.

I was afforded the privilege of attending some of Professor Moltmann's lectures in 2017 when he visited South Africa during the occasion of the centenary celebrations of the Faculty of Theology of the University of Pretoria. I have read Moltmann more than any theologian of stature during our time. I am fascinated by his theological acumen, which always addresses my theological enquiries. I agree with Klaus Nürnberger that 'Moltmann put the untapped positive potentials of an unfolding socio-political history back onto the theological agenda' (Moltmann, Tveit, Nürnberger \& Buitendag 2017:2). Amongst many subjects within his political trinitarian theology, I am fascinated by his views on creation, as it is expounded in his volume, God in Creation: An Ecological Doctrine of Creation (1985). What creates some thirst within me to re-look at his ecology is his trinitarianism that is characterised by mutuality, whereby he highlights relationships without hierarchy within the Trinity itself, between the Trinity and creation, and of course within creation itself (Bauckham 1995:7).

Moltmann is an influential contemporary theologian, yet as Deane-Drummond (2016) contends, his enormous contribution to ecotheology is scantily observed in the secondary literature. I am trying to collect and synthesize his ecotheology in this article, though this might not be as exhaustive an exercise as one would expect.

Theology and science are empirically tested as legitimate interdisciplinary reflections on the study and thinking on ecology (the study of organisms and their environments) and theology (the study of God and religious beliefs). This is a plausible epistemological consonance within ecological and theological narratives. It is highlighted by Van Huyssteen (in Gregersen \& Van Huyssteen 1998:37):

Because of the nature and the comprehensive resources of human rationality, the rationality of science and the rationality of religious reflection do seem to overlap at some very crucial junctures. The theologian shares with the scientist the crucial role of being a rational agent, of making the best possible rational judgement within a specific context and for a specific community. The theologian also shares with the scientist the fallibilism implied by the contextuality of rational decision making and thus the experiential and interpretative dimension of all our knowledge.

As a discipline, ecotheology is a form of constructive theology that focuses on the interrelationships of religion and nature, with a special focus on environmental concerns. Ecotheology reflects the positive response and sagacious thinking of contemporary religious thinkers to the ecological crisis. It advocates and reconfirms the trinitarian 
relationship of God-humanity-nature to approve the sacredness of the natural world and to realise the harmonious coexistence between human beings and the cosmos. It is a relationship explained by Jenson (1999:23): the actual life of the triune God with us is a true drama and is therefore conflicted and twisting. It encapsulates human behaviours, attitudes, spirituality, world-views and degradation or restoration and preservation of nature. It is all about human-environment explorations from theological perspectives, therefore calling for human responsibility or stewardship for creation. Failure to undertake this stewardship task can lead to human catastrophe. That is why Chibuye and Buitendag (2020:5) opine that 'Failure of human beings to regard creation as a community to which they (humans) belong is a proclamation of doom for the entire creation.' Ecotheology examines creation through the lenses of Scripture and Christian traditions. Religion and relationship to nature inspire theological thoughts or dictates on sustainability and the management of the environment. The emergence of modern ecotheology is a result of several beliefs:

- The Earth is growing increasingly endangered; action is needed.

- The Bible speaks of our relationship with and responsibility to the Earth, yet the contemporary church has remained largely silent concerning these messages.

- Christians need more accurate theological and biblical understandings of earthkeeping.

The focus of this paper is on Moltmann, with a special reference to his book: God in Creation: An Ecological Doctrine of Creation (1985). Historically, Christian theology is marked for an escape into a "theological retreat from cosmology into personal faith" (1985:34-36). Kroesbergen (2020:1) in company with Buitendag' s theology and nature negate this attitude by stating that the 'ecological crisis is serious and that we need to get as many people as possible on board to deal with it.' This has caused theology to demarcate and detach itself from cosmology. The Creator and the created constructed a gulf that seemed impassable. This detachment led to Christian theology's proclivity towards the problems of human (personal or societal) salvation or liberation. Conradie (1997:218) is correct that the retreat from cosmology and creation theology eventually led to an impasse in soteriology itself.

\section{Why ecotheology in South Africa?}

Ecology is concerned primarily with interactions among organisms, populations, communities, ecosystems, and the ecosphere (Miller 1992:83). It is a science that attempts to answer questions about how nature works. Basically, it is a study of the interaction of organisms with other organisms and their non-living environment of energy and matter (Miller 1992:79). It includes studies on climate, which is the average pattern of weather and temperature in a particular area over a long period of time (Foster and Peach 1998:14). Climatic conditions vary from year to year and on longer timescale (Grove1994:19), and for some time, the scientific community has warned of the potential for human activities to contribute to global climate change that negatively impacts bio quality. Briefly, there are three areas that have been identified as affected by climate change and which are subject to ongoing research: human health, migration and conflict 
(Serdeczny, Adams, Baarsch, Coumou et al 2016). This also affects natural resources, which is the term used to describe the basic materials and resources that are produced through the earth's own inherent natural processes and systems (Parry-Davies 2002:132). Natural resources include the planet's air water land; nutrients; resources in the soil, such as minerals; and animals.

Ecological degradation comes through human activities such as improper disposal of toxic waste, air pollution, deforestation etc. Kaoma (2015:15) is correct that the evergrowing population, soil erosion, pollution, and deforestation are not just ecological issues - they are gospel issues as well. These are mostly the result of irresponsible theology that disregards the sanctity of ecological interactions in the world. Moltmann confirms this in his Ethics of Hope (2012:133), where he states that 'human destruction of nature is based on a disturbed human to nature.' There are ecological critics who miss the fact that God's command was to tend the garden, not to exploit it. God never granted humans the absolute power to do with creation as they pleased. God himself modelled a pattern for environmental care which would please even the most jaded ecologist (Spring D and E 1974; Hendry 1980:172, 197). The absence of the prophetic voice in ecological responsibilities gave birth to modern science, which most of the time seems to marginalise God. The shift away from a world-view on theology is stretching all the time. Chittick (1984:120) is correct that scientific discoveries require that a biblicallybased theology of science be continuously updated. The updates need to be expressed and presented in terms which are clear to a person raised in modern culture. Ecological challenges, especially ecotheology, require forward-looking decision making that marries scientific diagnoses and technical innovation with socio-theological organisation and political debate around competing value systems. Experimentation, learning and the capacity to shift practices in light of new findings need to be part of the adaptation process.

It is to be noted also that Christianity is not the only religion that tends to abuse nature; many societies of non-Christian religions do so as well. The human population tends to forget that "God set down laws by which his people were to maintain an ecological sensitivity" (Badke 1991:77). The dominion over nature that God has assigned to humanity (Genesis 1:26; Psalm 8:6) entails human sensitivity to the Creator's moral and spiritual purposes for this planet (Henry 1986:16). This is the dream of Moltmann's ecological doctrine of creation under scrutiny in this paper.

Despite the continuing silence within the Christian Church in South Africa on ecological issues, the situation has changed significantly since the emergence of democracy. Universities' faculties of theology and religion have embraced ecological components into their curriculum wherein science and religion play some pivotal parts in trying to re-shape minds regarding nature. The government and communities continue to initiate programmes or networks such as Network of Earthkeeping Christian Communities (2002) and the South African Faith Communities' Environment Institute (2005).

\section{Moltmann the ecotheologian}

Moltmann's response to ecological abuses is to provide a Trinitarian theology of the environment that encompasses creation, redemption and anthropology. His theology of the environment, first expressed in God in Creation (1985) and later expounded in Ethics 
of Hope (2012), attempts to widen its eschatological focus by stressing that two types of subject, humanity and environment, are being redeemed in the coming of God's Kingdom. The environment itself, not just humanity, was created by God and therefore resists classification as an object. The environment is not simply the backdrop to humanity's relationship with God but in fact has its own relationship, both creative and redemptive, with God (Floyd 2019:124). According to Bentley (2005:327), Moltmann's starting point in speaking of God in the context of creation is the acknowledgement that there is a distinct and purposeful difference between God and creation (Moltmann 1996:307). It is in God that we find the uncreated, infinite and immortal, while creation contains the exact opposite of these descriptions.

Moltmann's book, God in Creation (1985), contributes to his ecotheology. Although the book is concerned with the totality of the relationship between God and the created order, it is nevertheless and consequently a stimulus to reflection on a theology of the environment and a theology of the church. The book itself was based on lectures delivered in 1984-85 in the Gifford lectures, which tend to deal with science and religion, and is placed both within Moltmann's wisdom and in his intellectual oeuvre. Moltmann elaborates his creation doctrine with a special view to the environmental crisis. The whole of Chapter II of God in Creation is addressing this environmental or ecological crisis. Theologians see this as panentheism, meaning all things are in God, and God is in all things. That is to say that he proposes that God permeates creation and extends beyond it (Floyd 2019:101). This proposal flows from Moltmann's rejection of classical theism, deism, pantheism, atheism, and process panentheism as viable descriptions of God's nature (Arnold 2016:17). One can observe that Moltmann's social doctrine of the Trinity has provided ecotheologians with a prominent early paradigm for 'greening' God's relationship to the world (Koster 2012:387). This is a theological argument of Moltmann, commencing with it or situating it as the foundation of his argument in Chapter I.

Moltmann's model of the social Trinity and a panentheistic infusion of the Divine life into the Church through the spirit sets the stage for a covenant that humanity has with the earth. Moltmann believes that according to the Bible, "Sabbath laws are God's ecological strategy, designed to preserve the life which God has created" (Moltmann 2001:189). Something else crucial to note is that dialectical movement is central to Moltmann's environmental theology as he stresses that the historical process is not simply subsumed by God's eschatological plan but drawn up into this plan. As creature yet as imago Dei, again the human being occupies a dialectical eccentric position. We "are" a body in addition to "having" a body; we are identified with our empirical environment, yet we transcend it (Moltmann 1969:154). While Moltmann does characterise God's Kingdom as an eternal Sabbath rest which mirrors the day of rest which concluded his creative act, this rest encompasses all of creation's history and does not subsume it. Moltmann expresses this:

The goal of this history of creation is not a return to the paradisal primordial condition. Its goal is the revelation of the glory of God...the new creation of heaven and earth in the kingdom of glory surpasses everything that can now be told about creation in the beginning (1985:207). 
So, the doctrine of the incarnation takes root in a theology of ecology. The totalising vision of the Church in The Power of The Spirit both politically and spiritually is brought into a cosmic dimension (Haynes 2006:10). Moltmann even moves towards a universalism position in the reconciliation of the world in Christ (2 Corinthians 5:18). This leads to some assumption that indeed, "theology looks at the natural world with regard to God's creating and redeeming activity" (Van Koosten Niekerk in Gregersen \& Van Huyssteen 1998:79).

Moltmann's theology in general and ecclesiology in particular is his thoroughgoing ecological concern. This ecological orientation has come to full maturity in his work on pneumatology (Kärkkäinen 2002:132), starting from The Church in the Power of the Spirit (1977). In order to develop a holistic philosophy of nature, his ecological doctrine of creation sees God's Spirit in all created beings (1985:98-103). It is quite interesting to note that Moltmann interwove the first three articles of the Apostles Creed in a trinitarian sense as a way of developing a pneumatological doctrine of creation with the indwelling of the Spirit of creation as a starting point. The sensible philosophy of the doctrine of ecology, as far as Moltmann is concerned, should be based on human understanding of God as the Creator, and that the Creator through his Spirit dwells in his creation as a whole, and in all created beings by virtue of his Spirit holds them together and keeps them alive (1985:100-101).

Moltmann's anthropology is fundamentally relational. He feels that human identity grows out of a primordial relationship with our Creator into a relationship with ourselves, our fellow human beings and the rest of creation. He points out this fundamentally relational nature of his anthropology:

...viewed as belonging within the enduring cohesion of the whole creation. Creation has its meaning for human beings, and human beings have their meaning for the community of creation. If we are to understand what human existence is, and what human beings are destined or called to be, we must see these human beings as belonging within the all-embracing coherences of God's history with the world, the history of creation and the history of redemption (1985:189).

For Moltmann writes, "the Creator indwells the creatures he has made, animates them, holds them in life, and leads them into the future of his kingdom" (1985:14). Moltmann thus re-envisions humanity within creation. He swims against the tide of traditional locating of humanity's imago Dei uniqueness in its individual rational capacity to 'subdue the earth'. Moltmann's trinitarian view of God enhances the social being of God, since God's likeness on earth is a social image. The human community in its perichoresis, which is a right, responsible, and loving relationship reflect and represent the triune God. He stresses that humanity discovers itself in relationships with itself and the rest of creation (Floyd 2019:118). The imago Dei is not a quality that humans possess by themselves; rather, it is an ongoing interaction between God and the human project (Peters 2000:154). It is for this reason that Moltmann extends this thought by saying that the imago Dei is a democratic society (1985:242). After all, God is relational and social. He occupies 'the vacated space in order to transfigure the whole of creation towards participation in the life of God' (Conradie 2008:85). 
Moltmann's emphasis on perichoresis in the Trinity has practical application. The trinitarian "community", characterised by mutual indwelling or inter-penetration, sets the pattern for human relationships. Reading Moltmann's The Trinity and the Kingdom (1993), one is left with the impression that his reflections on the Trinity bear on community formation and interdependence. He takes this further, saying that 'the community of God with his creation corresponds to the community of the Father, Son and the Holy Spirit' (2012:137). The church's goal is not just to reflect the imago Dei, but more specifically, the imago Trinitatis. The famous expression of this conviction is the axiom frequently attributed to Moltmann: "The Trinity is our social program." Moltmann's disdain for a metaphysical conception of the Trinity which focuses on the monarchical flows from the way such a depiction of God "generally provides the justification for earthly domination - religious, moral, patriarchal, or political" (Moltmann 1993:150). Humanity is the representation of God to the world and of the world to God, validated by the fact that humans are the priests of creation. This representative image finds fulfilment in Christ. Human imago Dei is not the only human mark, but humans are also imago mundi (image of the earth), which is embedded and immanent in the dynamic life process (1985:64). It is vital to see his definition of this imago mundi:

A microcosm in which all previous creatures are to be found again, a being that can only exist in community with all other created beings and which can only understand itself in this community (1985:186).

The Imago Dei concept, according to Moltmann (1985:190), has three implications:

i) A human being is the embodiment of all other creatures

ii) As imago Dei, human beings are God's proxy in the community of creation.

iii) In a Christian doctrine of creation human beings must neither disappear into the community of creation nor be detached from that community, since human beings are both imago Dei and imago mundi.

Unfortunately, humanity has moved away from this standpoint. They forget they are created to be perfected, and so in a different way is the whole creation (Gunton 2002:19). They no longer orient their cultures by nature on earth or the stars in the sky; instead, they created their cultures according to their own ideas. The human being has become the centre of the world, between heaven and earth, and the centre of its own self-created world. The world was made into the world of the human being, and nature on earth was demoted to being merely the environment for human civilisation (Moltmann 2011:20). If this was realised and understood, humanity would understand its expected harmonious and responsible relation with creation. For Moltmann, being made in God's image places a unique responsibility upon humanity.

As God's image, human beings are God's proxy in his creation, and represent him. As God's image, human beings are for God himself a counterpart, in whom he desires to see himself as if in a mirror. As God's image, finally, human beings are 
created for the Sabbath, to reflect and praise the glory of God which enters creation and takes up its dwelling there (1985:188).

A similar notion is expressed by Ward (1999:47): as an image in a mirror reflects reality, so humans are meant to reflect the nature and activity of God on the created earth. Floyd (2019:118) unravels this argument that humanity is called to take up responsibility commensurate to the status granted to them by God's grace. Moltmann argues that there is a certain way in which God wishes humanity to relate to creation: he wishes us to create a Sabbath community which reflects and praises the glory of God's Kingdom to come. We are, of course, entirely free to reject God's wishes and exploit the environment for materialistic ends; the consequences of this rejection are writ large on creation today. So what does the imago Dei charge humanity to do? Fundamentally, it is a charge to steward creation in such a way that it brings glory to God. The way to do this is revealed through an examination of the relationship between the messianic and eschatological elements of Moltmann's anthropology. As seen above, in the coming of God's Kingdom, all of creation, humanity included, will share in God's glory, becoming limitless and ideal versions of the limited and contingent examples evidenced within creation. Such perfection is, of course, impossible while creation remains other to God. However, Moltmann argues, God's eschatological glory can be reflected within creation through human stewardship. The imago Dei is humanity's ontology, not their telos. Their telos, Moltmann claims, is the imago Christi, the image of Christ. Moltmann drives this point home:

In the messianic light of the gospel, the human being's likeness to God appears as historical process with an eschatological termination; it is not a static condition. Being human means becoming human in the process (1985:188).

Moltmann's ecological theology is based on the premise that creation and redemption are inextricably intertwined. God's love for creation is shown by his volitional act to bring it into being and sealed by his promise to eventually bring about its redemption. This is enhanced by Moltmann's concept of "Kingdom of Glory", which is the divinely promised fulfilment of God's glory in the full freedom in a community of humans as well as the liberation of creation itself from bondage to decay (1970:9). Moltmann (1985:39) writes:

The key promise for the development of my eschatological vision is to be found in Isaiah's vision: 'The whole earth is full of his glory' (6:3). From that I concluded that this is the goal of creation from the beginning, and that with the creation of a world differentiated from himself and non-divine, God undertook a first kenosis: God involved himself in this endangered creation, and entered into it through his Word and Wisdom.

Moltmann expands his ecological doctrine in his other book, The Coming of God (1996), where he argues that premillennial eschatology, the belief in the coming kingdom of God on earth, does not dampen activism for the transformation of the world. This belief, as 
far as Moltmann is concerned, energises social ecological activism (Olson 2013:454). In this book, Moltmann aims at encouraging and equipping Christian environmentalism.

This relationship of humanity and creation or nature is also highlighted by some African theologians. For instance, Mugambi and Kirima (1976:9) assert:

According to African thought and belief, man is not an isolated creature. He is only part of the universe, which is full of animals, plants, and inanimated objects. All these components are related to each other in various ways and all of them are dependent on the supreme God for their first appearance and for their continued existence.

This assertion of the relationship of humanity with creation is occupying the centre of environmental sciences and theology on a larger scale. Even the evangelical theologian, Erickson (1983:377) could exclaim: "Since inanimate material also come from God, I am at base, one with nature, for we are members of the same family."

\section{Ecology and theology are inseparable for Modern Narrative}

The resurgence of environmental sciences in academia opens the doors for ecotheology. Theology as science is expected to ascend the stage of dialogues on ecological issues. Moltmann (2016:5) drives this point home:

A new paradigm is emerging in which human culture and the nature of the earth are differently bound together than in the paradigm of the modern age. The modern age was determined by the seizure of power by humans over the earth and the elements and energies of nature. As an image of God, the human being is exceptional and the dominium terrae - lordship over the earth - is his destiny.

The inescapable and undeniable reality is that academia is a space of inter-disciplinary explorations. Science and theology are far closer to each other than before. Moltmann's argument that "creation has its meaning for human beings, and human beings have their meaning for the creation" (1985:189) is relevant for ecotheological endeavours. This theology-science synergy balances practical or moral questions in the natural realm. Neither of the two claims supremacy over the other; they regard each other as partners with God for creation's eschatological realisation and fulfilment. They are the two companions, walking together in the light. As Buitendag and Simut (2021:2) assert: 'Science and theology both shun delusion. 'Both are pursued by truth-seeking communities.'

Ecotheology can help because the understanding of nature and the self-understanding of humans in the modern age were both coined by our modern anthropocentric theology and ethics. The new challenges are now that humans who inflict sickness and wounds into creation should take responsibility for healing the earth. That this is a human task is unquestionable. Theologians are called upon to change the so-called world religions into earth religions with reverence for the earth, that is, the biblical Sabbath of the land (Moltmann 2016: 6). Christianity is called upon to change from the traditional gnostic spirituality of pronouncing that "we are only guests on earth, our homeland is in heaven" 
to seeing that the earth is our home in both this world and the world to come. Because we expect the new earth on which righteousness dwells, we are to be faithful to the earth. This earth is not our guesthouse, it is our home. If we are only guests on earth, we are not responsible for the guesthouse when it becomes a vale of tears. Before we work on earth, we are taken from the earth and return to the earth. Spirituality develops where God's spirit is expected and experienced. God is in nature. Thus, as ontologically related to creation, the Christian must first consider her conscious posture toward the natural world (Jorgenson 2017:98). Furthermore, as Kaoma asserts, "African Christianity should respond aggressively to the challenges posed by the recurring ecological crisis" (2015:15).

The purpose of creation is therefore not to serve as the dwelling place for all that is created but to serve as the perfect venue where God and the created can feast in fellowship. Creation is a platform on which God is to be glorified and where humanity must enjoy fellowship with God. The Church is therefore not only the gathering of people in order to worship and fellowship but becomes the ideal vehicle through which God can bring restoration to creation through God's Spirit (Moltmann 1992:64). Creation is a space where humanity rediscovers itself and reaches toward the creator in a sensible way. In his Ethics of Hope, Moltmann burdens the Christian reader with the urgent task of discarding detrimental, traditional anthropocentric views of nature for a life-affirming, unfolding, covenantal concept of creation (2012:142-143). They need to take a gigantic leap of acquiring knowledge of the trinitarian creation model suggested by Moltmann's ecological doctrine i.e. God-Creation-Humanity. Human beings must find out what their God-given meaning for the creation is, and then their sense of responsibility will be ignited (Olan'g 1991:44). By this, Moltmann seeks to promote Christian environmentalism that emphasises the earth as God's habitat and the scene of God's coming kingdom of glory. It is not humanity's to do with as it wishes because it is where God dwells. Harming the earth is harming God. Toward the end of God in Creation, Moltmann discusses the future kingdom of glory as the "Sabbath" in which God rests from his creative work (Olson 2013:470). This rest is a precursor to human responsibility to care for the earth. Rest is a desist from exhausting nature in order to give it a period for replenishment.

Ecologists and theologians agree that anthropology should be situated at the centre of ecological management. Theologians generally reinterpret the concept "subdue' the earth sensibly: it does not necessarily mean to destroy or abuse the earth for selfish reasons but to assume that the earth is 'our home' offering them the 'living space for a unique and diverse community of living things' (Moltmann 2019:24). It denotes the idea of being able to maintain nature and to keep it in a God-satisfying condition. Humans are not masters over creation but managers thereof. This fact is stressed by Moltmann that "As God's image, human beings are for God himself a counterpart, in whom he desires to see himself as if in a mirror" (1985:188). As counterparts of God, human beings "represent his glory and his will" (1985:190). As representatives, it is therefore expected of humans to possess sense of responsibility and accountability. They must exhibit the characteristics of God to creation. The ecological doctrine of creation should be understood to mean that the breadth of God's presence touched everything so that everything could reflect God's mercy and goodness. As Dearborn (in Stackhouse 2003:60) asserts: 
Creation's goodness was not equated with comfort or ease but rather with its ability to reflect God's own goodness and to aid in sharpening one's own character toward such goodness.

Conradie, in agreement with Moltmann, alludes to the fact that Christianity bears a huge burden of guilt, as it has given religious support to the notion that the world has been created primarily for the benefit of human beings (2011:5). Moltmann is of the conviction that Christianity plays a huge role towards the current ecological crises.

The Christian belief in creation as it has been maintained in the European and American Christianity of the western churches is therefore not guiltless of the crisis in the world today (1985:21).

Erickson (1993:53) stresses this same notion that there is an ecological crisis in our world today and that some of the blame for this crisis is Christianity, especially conservative or evangelical Christianity. The indictment is not just a single charge, but a whole series of them. For instance;

1. The call to have dominion (Gen 1:28) entails treating the earth as intended solely for the good of the human; the result has been the rape of creation (McHarg 1969:26)

2. Modern science and technology's exploitation of the earth has been condoned by Christianity (White 1973:43-54).

3. Christianity has promoted a dualism that regards the natural, the physical, and the secular as of less value than the spiritual and the otherworldly (Berry 1973:135).

4. Belief in the second coming, which will usher in the complete and perfect reign of Christ, has in effect removed any sense of need for ecological concerns (Granberg- Michaelson 1984:33-34).

Therefore, sound ecotheology perceives humanity's dominion as a calling to exercise stewardship of care, not an unlimited right to do as they please with God's creation (Ward 1999:47). Their life mission is to help make the world fruitful and to bring the entire ecosystem to its proper fulfilment. Imago Dei empowers them for proper ecological stewardship in partnership with God. Kaoma (2015:23) highlights the fact that "God intended us to be Earth-keepers or Earth-servers as opposed to Earth-destroyers." This calls for eco-justice, which is at the centre of ecotheological dialogues, as it calls humanity towards responsible and just living to help correct ecological as well as economic imbalances. Humanity is called upon to recalculate its essence and purpose of being partners with God in ecological management. Nürnberger (2016:90) makes this appeal:

We should not take more from nature than we are entitled to. We should also not expect to be granted a life that never reaches its limit. We cannot hope for an infinite continuation of the world we know. This is simply not the world that God has 
created and continues to create, and we better adjust our faith assumptions to the realities of this world.

Theological considerations must go down to earth, where human responsibility for the continuous replenishment of creation is to be undertaken. Ecotheology's liberative role is not just for ecosystems but also for human survival. This solidarity with the contingent natural world has a critical function, for it shows that neither humans nor nature are divine, nor should either be demonised as evil. Of course, important ecological consequences must follow from an awareness of solidarity with our fellow creatures. And on a personal level, it can begin to reverse the problem of alienation from the physical body. Humans must return to the sense of oneness with all that has been created. Even the Islamic faith has a positive consideration towards nature with humans as responsible agents to ensure sustainability and maintenance of the environment. According to Islam, humans have the intellectual capacity to learn. By reflecting on the universe, they have a capacity to gain knowledge of God (Qur'an 2:31-33). Human beings have been "honoured with goodness" (17:70) in that men and women are created with the innate capability to recognise goodness and to respect virtue (Ozalp in Pearson 2019:103). Whenever the Qur'an gives responsibility to humans, it comes with an obligation to follow through with the responsibility and the resultant accountability before God. In the words of Moltmann, nature is not our property to do with as we wish. We human beings are "one part of the wider family of nature, which we have to respect" (1999:99).

\section{Conclusion}

Ecotheologians are of the strong conviction that "Science enlarges and changes our view of the known world" (Drees in Gregersen and Van Huyssteen 1998:90). Trying to separate theology and ecology is comparatively suicidal. Complementarity leads to the synergy between metanarratives and scientific discoveries into symbiotic relationships. Ecological responsibility is a cultural synthesis that humanity is squarely responsible for the stewardship of the earth. Culture is where religion happens; religion is located within human culture. Religion has emerged within the cultural phase of evolution (Hefner 2000:91).

Moltmann's trinitarian theology is eclectic, and its ecology is wrapped around pneumatology and anthropology. The Spirit gives life to creation, and humanity plays a pivotal role in the eschatological fulfilment of the created sphere. Humanity develops a culture that is either destructive or constructive to the universe. In the past, theology was too humanistic in situating a human being as the controller to do what he likes. The emergence of ecotheology assists scholars to balance and maintain a stable and theologically sensible form of stewardship. This is to take a command from the perichoretical example for us to dwell together with God and creation as partners towards creation fulfilment. Humans can objectify reality, seeing it from above as it were, 'with the eyes of God' (Nürnberger 2016:129). Indeed, humans are the weavers or gatekeepers according to the natural order that is at the core of imago Dei (Hefner 1998:539-543). Humans are free creators of meanings emerging from a long evolutionary process, including a symbiotic co-evolution of biology and culture (Hefner 1998:539-543). Moltmann's doctrine of creation acts as the basis of an ecologically sensitive ethic. The 
field of ecotheology appraises Moltmann's theologically rigorous application of Christian theology to social, political, and environmental issues (McGrath 1999:120).

The church should continue to exist as an academy of justice carrying out its moral responsibility to creation. Nature, including humanity, has worth because God is its creator, and humans create cultures and social systems expected to carry, sustain and manage creation in a responsible way. The creator endows creatures with reason in order that, hearing his intelligible word of promise and command, they may know him, and so love and obey him (Webster 2013:124). The bottom line and the heartbeat of Moltmann regarding ecological understanding is that of stewardship, a notion that is expressed by Rossing and Buitendag (2020:3) as follows:

We all share the same earth and that we all, believers and unbelievers, theologians and scientists the like, should move to a point where we all share the value of this planet.

Ecology and theology are sciences in human hands, and they therefore demand anthropological responses through the processes of reviews, reflections, scrutinies and human-environment relationship evaluations through interactions. Out of the Reformation tradition of introspective processes, theology and ecology should embark on 'ongoing theological reflection, which is required for the sake of clarification' (Conradie 2020:7). Clarification should refocus on positionalities of God-humancreation interactions.

\section{BIBLIOGRAPHY}

Arnold, Jr, G.P. 2016. Searching for the Trinity: A Summary and Critique of Jürgen Moltmann's Theological Method and Theology of God. A Paper Presented to Dr Todd Miles, Western Seminary, Portland. In Partial Fulfilment of the Requirements for the Course THS 660, 20th Century Theology.

Badke, W.B. 1991. Project Earth: Preserving the world God created. Oregon: Multnomah Press.

Bauckham, R. 1995. The theology of Jürgen Moltmann. Edinburgh, T \& T Clark. Bentley, W. 2005. The Kingdom of God in Moltmann's eschatology: A South African perspective, Dutch Reformed Theological Journal = Nederduitse Gereformeerde Teologiese Tydskrif $326-335$.

Berry, W. 1973. A secular pilgrimage in Barbour, I.G. (ed), Western man and environmental ethics reading. Mass: Addison-Wesley, 94-155.

Buitendag, J. and Simut, C.C 2021 Nature as God: A juxtaposition of Vito Mancuso and Alexander von Humboldt in their search for understanding reality, HTS Teologiese Studies/ Theological Studies 77(3). Online: a6525. https://doi. org/10.4102/hts. v77i3.6525.

Chibuye, L. and Buitendag, J. 2020, The indigenisation of eco-theology: The case of the Lamba people of the Copperbelt in Zambia, HTS Teologiese Studies/ Theological Studies 76(1). Online: a6067. https://doi. org/10.4102/hts. v76i1.6067. 
Chittick, R.E. 1984. The controversy: Roots of the creation-evolution conflict. Oregon: Multnomah Press.

Conradie, E.M. 1997. "Reconstructing an Ecological Cosmology: A South African Contribution." Scriptura 61 (1997), 213-230.

Conradie, E.M. 2008. The Justification of God? The Story of God's Work According to Jürgen Moltmann: Part 1. Scriptura 97, 76-90.

Conradie, E. 2011. Christianity and earthkeeping: In search of an inspiring vision. Stellenbosch: Sun Press.

Conradie, E.M. 2015. The Earth in God's economy: Creation, salvation and consummation in ecological perspective (10): Studies in Religion and the Environment/Studies zur Religion und Umwelt. Lit Verlag GmbH \& Co. KG Wien.

Conradie, E.M. 2020. The four tasks of Christian ecotheology: Revisiting the current debate, Scriptura 119, 1-13. Online: http://scriptura.journals.ac.za http://dx.doi.org/10.7833/119-1-1566 (Accessed 11 July 2021).

Deane-Drummond, E.E. 2016. Ecology in Jurgen Moltmann's theology. Wipf \& Stock, an Imprint of Wipf and Stock Publishers.

Dearborn, K.L. 2003. Recovering a trinitarian and sacramental ecclesiology. in Stackhouse Jr, J.G. Evangelical ecclesiology: Reality or illusion. Grand Rapids: Baker Academic Books, 39-73.

Drees, W.B. 1998. The significance of scientific images: A naturalist stance. in Gregersen, N.H. and Van Huyssteen, J.W. Rethinking theology and science: Six models for the current dialogue. Grand Rapids: W.B. Eerdmans Publishing Company, 87-120.

Erickson, M.J. 1983. Christian theology. Volume 1. Grand Rapids: Baker Book House. Erickson, M.J. 1993. The evangelical mind and heart: Perspectives on theological and practical issues. Grand Rapids: Baker Book House.

Floyd, A. 2019. A critical and comparative analysis of Jürgen Moltmann's and Gordon Kaufman's environmental theologies. Ph.D. dissertation, University of Manchester.

Foster, A. and Peach, S (eds). 1998. Geography of the world. London: The Dorling Kindersley.

Granberg-Michaelson, W. 1984. A worldly spirituality: The call to redeem life on earth. San Francisco: Harper \& Row.

Grove, A.T. 1994. The changing geography of Africa (2 ed). Oxford: Oxford University Press.

Gunton, C.E. 2002. The Christian faith: An introduction to Christian doctrine. Oxford: Blackwell Publishing.

Haynes, D. 2006. Jürgen Moltmann's missiological outlook. Submitted to Paideia Student Spring Conference 2006. Dallas Baptist University.

Hefner, P. 1998. The spiritual task of religion in culture: An evolutionary perspective, Zygon 33:535-544.

Hefner, P. 2000. Imago Dei: The possibility and necessity of the human person In Gregersen, N.H., Drees, W. B. and Görman, U (eds), The human person in science and theology. Grand Rapids: W.B. Eerdmans Publishing Company, 73-94.

Hendry, G.S. 1980. Theology of nature. Philadelphia: Westminster Press. 
Henry, C.F.H. 1986. Christian countermoves in a decadent culture. Oregon: Multnomah Press.

Jenson, R.W. 1999. Systematic theology: The works of God, Vol 2. Oxford: Oxford University Press.

Jorgenson, K. 2017. Cosmic interrelations of the divine Spirit: Jürgen Moltmann, God and Creation, Islamochristiana 43: 93-114.

Kärkkäinen, V. 2002. Toward a pneumatological theology: Pentecostal and ecumenical perspectives on ecclesiology, soteriology, and theology of mission. Maryland: University Press of America.

Kaoma, K.J. 2015. The creator's symphony: African Christianity, the plight of earth and the poor. Dorpspruit, South Africa: Cluster Publications.

Kroesbergen, H. 2020. Religious diversity, ecology and grammar, HTS Teologiese Studies/ Theological Studies 76(1). Online: a6064. https://doi.org/ 10.4102/hts. v76i1.6064.

Koster, H.P. 2012. Questioning eco-theological panentheisms: The promise of Kathryn Tanner's theology of God's radical transcendence for ecological theology, Scriptura 111(3): 385-394.

McGrath, A.E. 1999. Science and religion: An introduction. Oxford: Blackwell Publishing.

McHarg, I.L. 1969. Design with nature. Garden City, N.Y: Natural History.

Miller, G.T. 1992. Living in the environment: An introduction to environmental science (7 ed). Belmont, CA: Wadsworth Publishing Company.

Moltmann, J. 1969. Religion, revolution and the future. New York: Charles Scribner's Sons.

Moltmann, J. 1970. Theology as eschatology. In Herzog, F. (ed), The future hope: Theology as eschatology. New York; Herder \& Herder: 1-50.

Moltmann, J. 1985. God in creation: An ecological doctrine of creation. Translated by Margaret Kohl. Munich: SCM Press.

Moltmann, J. 1985. The world in God or God in the world. In Bauckham, R. (ed), God will be all in all: The eschatology of Jürgen Moltmann. Minneapolis: Fortress Press.

Moltmann, J. 1992. The church in the power of the Spirit. Translated by M. Kohl. London: SCM Press.

Moltmann, J. 1993. The Trinity and the Kingdom, trans. Margaret Kohl. Minneapolis: Fortress.

Moltmann, J. 1996. The coming of God: Christian eschatology. Translated by M. Kohl. London: SCM Press.

Moltmann, J. 1999. God for the secular society: The public relevance of theology, trans. Margaret Kohl. Minneapolis: Fortress.

Moltmann, J. 2001. The destruction and healing of the earth in Stackhouse, M.L. (ed), God and globalization. Harrisburg: Pennsylvania.

Moltmann, J. 2011. A common earth religion: World religions from an ecological perspective. The Ecumenical Review 63(1): 16-24, World Council of Churches.

Moltmann, J. 2012. Ethics of hope. Minneapolis: Fortress.

Moltmann, J. 2016. The future of theology, The Ecumenical Review 68(1):3-13. 
Moltmann, J., Tveit, O.F., Nürnberger, K. \& Buitendag, J., 2017, 'Tribute, hope and reconciliation', HTS Teologiese Studies/ Theological Studies 73(1). Online: a4724. https://doi.org/ 10.4102/hts. v73i1.4724.

Moltmann, J. 2019. The spirit of hope: Theology for the world in peril. Louisville, KY: Westminster John Knox Press.

Mugambi, J and Kirima, N. 1976. The African religious heritage. Nairobi: Oxford University Press.

Nürnberger, K. 2016. Faith in Christ today: Invitation to systematic theology, Vol II. Pietermaritzburg: Cluster Publications.

Olan'g, H.D. 1991. Moltmann's theology of creation: Its relevance for African context with reference to the ecological crisis. M.Div. thesis, University of Nairobi, Kenya.

Olson, R. E. 2013. The journey of modern theology from reconstruction to deconstruction. Downers Grove: InterVarsity Press.

Ozalp, M. 2019. Caring for God's creation: An Islamic obligation in Pearson, C. (ed.), Enacting public theology. Stellenbosch: SunMedia, 99-113.

Parry-Davies, D Hoogervorst, A and Janse Van Rensburg, E. 2002. The Enviropaedia World Summit Edition: Environmental encyclopaedia \& networking directory for southern Africa. Simonstown: Eco-Logic Publishing Company.

Peters, T. 2000. God - the world's future: Systematic theology for a new era (2nd ed.). Minneapolis: Fortress Press.

Rossing, B.R. and Buitendag, J. 2020. 'Life in its fullness: Ecology, eschatology and ecodomy in a time of climate change', HTS Teologiese Studies/Theological Studies 76(1). Online: a6245. https://doi. org/10.4102/hts. v76i1.6245.

Serdeczny, O, Adams, S, Baarsch, F, Coumou, D, Robinson, A, Hare, W, Schaeffer, M, Perrette, M and Reinhardt, J. 2016. Climate change impacts in Sub-Saharan Africa: from physical changes to their social repercussions. Reg Environ Change. Online: DOI 10.1007/s10113-015-0910-2.

Spring, D and E. 1974. Ecology and religion in history. New York: Harper \& Row.

Van Huyssteen, J.W. 1998. Postfoundationalism in Theology and Science: Beyond Conflict and Consonance, (13-49) in Gregersen, N.H. and Van Huyssteen, J.W. (eds.), Rethinking theology and science: Six models for the current dialogue. Grand Rapids: W.B. Eerdmans Publishing Company.

Van Kooten Niekerk, K. 1998. A critical realist perspective on the dialogue between theology and science (51-86) in N.H. Gregersen, N.H and Van Huyssteen, J.W. (eds), Rethinking theology and science: Six models for the current dialogue. Grand Rapids: W.B. Eerdmans Publishing Company.

Ward, K. 1999. God, faith and the new millennium: Christian belief in an age of science. Oxford: Oneworld Publications.

Webster, J. 2013. The domain of the Word: Scripture and theological reason. London: Bloomsbury $\mathrm{T} \& \mathrm{~T}$ Clark.

White Jr, L. 1973. The historical roots of our ecological crisis (43-70) in Barbour, I.G. (ed), Western man and environmental ethics reading. Mass: Addison-Wesley. 